\title{
KURSUS PRA-NIKAH: KONSEP DAN IMPLEMENTASINYA (STUDI KOMPERATIF ANTARA BP4 KUA KEC. PONTIANAK TIMUR DENGAN GKKB JEMAAT PONTIANAK)
}

\author{
Muhammad Lutfi Hakim \\ Program Studi Ahwal Al-Syakhsiyyah STIS Syarif Abdurrahman Pontianak \\ Email: luthfyhakim@gmail.com
}

\begin{abstract}
Marriage is a holly and sacred bond. Hence, before getting married, spouses should make good preparations and considerations by having pre-wedding counseling in order that the marriage will be harmonious and long lasting without divorce ending. This is based on a field research on pre-wedding counseling known as suscatin held by KUA, Kec. Pontianak Timur, and that by GKKB Jemaat Pontianak. Both pre-marriage counseling programs are differently applied but they have common purposes: providing marital guidance, description, and preparation in order that spouses can maintain their harmonious marriage: sakinah, mawadah, and rahmah.
\end{abstract}

Keywords: Pre-wedding Counseling, KUA Kec. Pontianak Timur, GKKB Jemaat Pontianak.

\begin{abstract}
Abstrak
Pernikahan adalah sebuah ikatan yang suci dan sakral. Sebelum mengikat sebuah ikatan yang suci tersebut, para calon suami-isteri harus mempersiapkan sematang-matangnya. Banyak sekali pasangan suami-isteri menikah, akan tetapi kehidupan keluarganya tidak berlangsung dengan harmonis, bahkan terjadi perceraian. Oleh karena itu, diperlukan bimbingan, arahan, dan konseling sebelum melakukan sebuah pernikahan tersebut. Tujuannya adalah supaya para calon pasangan suami-isteri tersebut sudah siap untuk membina sebuah keluarga yang sakinah. Tulisan ini merupakan hasil dari penelitian lapangan (field research) dengan menggunakan pendekatan deskriptif-analitik. Kursus pra-nikah di KUA Kec. Pontianak Timur dikenal dengan istilah Suscatin, sedangkan di GKKB Jemaat Pontianak dikenal dengan istilah konseling pra-nikah. Pelaksanaan kursus pra-nikah diantara keduanya memiliki perbedaan dan persamaan masingmasing. Perbedaannya lebih kepada hal yang teknis, sedangkan persamaanya terletak dari tujuan diadakannya kursus pra-nikah tersebut, yaitu memberi arahan, gambaran persiapan, bimbingan, dan konseling kepada calon pasangan suami-isteri untuk dapat membina rumah tangga yang sakinah, mawaddah, dan rahmah.
\end{abstract}

Kata Kunci: Kursus, Pra-Nikah, KUA Kec. Pontianak Timur, GKKB Jemaat Pontianak 


\section{Pendahuluan}

Kualitas sebuah perkawinan ${ }^{\mathbf{1}}$ sangat ditentukan oleh kesiapan dan kematangan kedua calon pasangan nikah dalam menyongsong sebuah kehidupan berumah tangga. Tujuannya adalah untuk membina sebuah rumah tangga yang sakinah, mawaddah, dan rohmah. Ketentuan seperti ini dapat dianalogikan dengan mengendarai sebuah mobil. Untuk mengendarai sebuah mobil dengan selamat, sopir harus mengetahui tata cara untuk menyupir dan medan yang akan ditempuh. Seorang sopir harus kursus menyetir terlebih dahulu sampai mahir. Apabila tidak, maka mobil tersebut dapat menabrak pengendara yang lain. Apalagi jika kita terapkan pada sebuah pernikahan yang sifatnya sakral. Oleh karena itu, diperlukannya pelatihan dan pembekalan singkat (short course) dalam bentuk kursus pra-nikah. Kursus pra-nikah ini merupakan salah satu upaya penting dan strategis untuk mewujudkan keluarga yang sakinah. ${ }^{2}$

Kursus pra-nikah ini dilatarbelakangi oleh banyaknya pernikahan yang hancur karena kurangnya persiapan, atau terkesan terburu-buru. Kenapa demikian? Karena banyak sekali para pasangan suami isteri yang tidak memikirkan dan merencanakan halhal yang berkaitan dengan pernikahan dan kehidupan setelah itu. Selain itu, dalam membina sebuah rumah tangga, terkadang muncul persoalan-persoalan yang dapat menimbulkan konflik. Apabila konflik tersebut tidak dapat diselesaikan dengan ma'ruf, maka tidak sedikit pasangan yang berunjung pada putusnya sebuah ikatan perkawinan. Hal tersebut dapat dilihat dari data yang penulis dapatkan dari Pengadilan Agama Pontianak:

1 Beberapa penulis terkadang menyebut pernikahan dengan kata perkawinan. Dalam Bahasa Indonesia, “perkawinan” berasal dari kata "kawin”, yang artinya membentuk keluarga dengan lawan jenis, melakukan hubungan kelamin atau bersetubuh. Istilah ini digunakan secara umum untuk tumbuhan, hewan, manusia dan menunjukkan proses generatif secara alami. Sedangkan "nikah”, hanya digunakan pada manusia, karena mengandung keabsahan secara hukum nasional, adat istiadat, dan hukum agama. Lihat: M. A. Tihami dan Sohari Sahrani, Fikih Munakahat: Kajian Fikih Nikah Lengkap, Cet. III (Jakarta: Rajawali Press, 2013), 7. Berdasarkan perbedaan definisi pernikahan dan perkawinan yang dipaparkan oleh Tihami sebelumnya, dalam tulisan ini, penulis menggunakan istilah perkawinan bagi perkawinan yang sah menurut agama. Sedangkan kata pernikahan, penulis gunakan untuk perkawian yang sah menurut agama kemudian dicatatkan.

2 Keluarga sakinah adalah keluarga yang didasarkan atas perkawinan yang sah, mampu memenuhi hajat spiritual dan material secara serasi dan seimbang, diliputi suasana kasih sayang antara internal keluarga dan lingkungannya, mampu memahami, mengamalkan dan memperdalam nilai-nilai keimanan, ketakwaan dan akhlaqul karimah. Pasal 1 ayat (3) Peraturan Direktur Jenderal Bimbingan Masyarakat Islam Kementerian Agama Nomor DJ.II/542 Tahun 2013 Tentang Pedoman Penyelenggaraan Kursus Pra-Nikah. 
Table $1^{3}$

Data Statistik Perkara yang Masuk di Pengadilan Agama

Tahun 2009-2013

\begin{tabular}{|c|c|c|c|c|c|}
\hline \multirow{2}{*}{ No. } & \multirow{2}{*}{ Tahun } & \multicolumn{3}{|c|}{ Jenis Perkara } & \multirow{2}{*}{ Jumlah } \\
\cline { 3 - 5 } & & Cerai Gugat & Cerai Thalak & dll & \\
\hline 1. & 2009 & 63 & 27 & 17 & 107 \\
\hline 2. & 2010 & 613 & 226 & 209 & 1048 \\
\hline 3. & 2011 & 703 & 239 & 275 & 1217 \\
\hline 4. & 2012 & 876 & 271 & 363 & 1510 \\
\hline 5. & 2013 & 856 & 298 & 406 & 1560 \\
\hline
\end{tabular}

Sumber: Pengadilan Agama Pontianak

Dari tabel di atas, terlihat bahwa dari tahun ke tahun, jumlah pasangan yang cerai, baik cerai thalak maupun cerai gugat, semakin signifikan. Selain disebabkan oleh beberapa faktor, seperti ekonomi, latar belakang keluarga, lingkungan tempat tinggal, campur tangan orang tua dalam masalah keluarga, dan sebagainya. Namun, menurut hemat penulis, faktor utama penyebabnya adalah ketidakpedulian suami dan istri atas tugas masing-masing, dan juga ketidaksiapan mereka untuk membangun rumah tangga. Apabila seseorang kurang berpengetahuan dan kurang siap, maka orang itu tidak akan dapat mencapai tujuan yang diharapkan. Oleh karena itu, perlu adanya pelatihan-pelatihan tertentu sebelum dilaksanakannya sebuah pernikahan yang suci untuk mengajarkan dan membekali para pasangan dalam menghadapi likaliku kehidupan berrumah tangga.

Dalam penelitian ini, jenis penelitian yang penulis gunakan adalah penelitian lapangan (field research). Maksudnya adalah data yang dijadikan rujukan dalam penelitian ini berupa fakta-fakta di lapangan, yaitu data-data lapangan yang ada di Kantor Urusan Agama Kec. Pontianak Timur dan di GKKB Jemaat Pontianak. Caranya ialah dengan menghimpun informasi yang dilakukan melalui wawancara yang mendalam dari sejumlah informan, dokumen-dokumen, observasi, buku-buku

3 Pengadilan Agama Pontianak, Data Statistik Perkara yang Masuk di Pengadilan Agama (http://www.pa-pontianak.go.id/index2.php?option=com_wrapper\&view= $\quad$ wrapper\&Itemid= 136, diakses, 28 Maret 2014). 
dan karya ilmiah yang mendukung dalam penulisan penelitian ini. Setelah datanya terkumpul, kemudian penulis menganalisanya secara kualitatif. ${ }^{4}$

\section{Konsep Kursus Pra-Nikah}

\section{Definisi Kursus Pra-Nikah}

Pada Pasal 1 ayat (3) Peraturan Direktur Jenderal Bimbingan Masyarakat Islam Kementerian Agama Nomor DJ.II/542 Tahun 2013 Tentang Pedoman Penyelenggaraan Kursus Pra-Nikah, kursus pra-nikah adalah pemberian bekal pengetahuan, pemahaman, keterampilan dan penumbuhan kesadaran kepada remaja usia nikah dan calon pengantin tentang kehidupan rumah tangga dan keluarga. ${ }^{5}$ Menurut Muhammad Dani, kursus pra-nikaha ialah pembekalan dan pengarahan ke pada calon pengantin yang akan membentuk sebuah keluarga baru. ${ }^{6}$

Ada dua tujuan yang ingin dicapai dalam kursus pra-nikah, yakni tujuan umum dan tujuan khusus. Adapun tujuan umum diberlakukannya kursus pra-nikah adalah untuk mewujudkan keluarga yang sakinah, mawaddah, warahmah melalui pemberiaan bekal pengetahuan, peningkatan pemahaman dan keterampilan tentang kehidupan rumah tangga dan keluarga. Sedangkan tujuan khusus dari kursus pranikah adalah untuk menyamakan persepsi badan/lembaga dan terwujudnya pedoman penyelenggara kursus pra-nikah bagi remaja usia nikah dan calon pengantin. $^{7}$

Jadi, dari definisi yang telah dijelaskan sebelumnya, dapat kita pahami bahwa kursus pra-nikah adalah bimbingan dan pembekalan kepada calon pengantin (calon suami-isteri) sebagai bekal pengetahuan untuk mengarungi sebuah bahtera rumah

4 Analisis data kualitatif adalah upaya yang dilakukan dengan jalan bekerja dengan data, mengorganisasikan data, memilah-milahnya menjadi satuan yang dapat dikelola, mensintesiskannya, mencari dan menemukan pola, menemukan apa yang penting dan apa yang dipelajari dan memutuskan apa yang dapat diceritakan kepada orang lain. Lihat: Bogdan, R.C. and Biklen, K., Qualitative Research for Education: An Introduction to Theory and Methods (Boston: Allyn and Bacon.Inc, 1992), 153.

${ }^{5}$ Pasal 1 Ayat (1) Peraturan Direktur Jendral Bimbingan Masyarakat Islam No. DJ.II/542 Tahun 2013 Tentang Penyelenggaraan Kursus Pra-Nikah.

${ }^{6}$ Data diperoleh dari hasil interview dengan Penghulu Fungsional KUA Kecamatan Pontianak Timur bernama M. Dani, S.Ag., tertanggal 26 Januari 2015.

7 Badaruddin, Petunjuk Teknis Penyelenggaraan Kursus Pra-Nikah; Modul Kursus Pra-Nikah (Yogyakarta: Seksi Urusan Agama Islam, 2012), 2. 
tangga yang diberikan oleh petugas BP4. ${ }^{8}$ Hal-hal yang akan dibahas dan diberikan kepada calon pengantin adalah materi-materi yang berkaitan tentang perkawinan.

\section{Dasar Hukum Kursus Pra-Nikah}

Adapun dasar hukum dilaksanakannya kursus pra-nikah berdasarkan Peraturan Direktur Jendral Bimbingan Masyarakat Islam adalah sebagai berikut ini: ${ }^{9}$

a. Undang-Undang Nomor 1 Tahun 1974 tentang Perkawinan (Lembaran Negara Republik Indonesia Tahun 1974 Nomor 1, Tambahan Lembaran Negara Republik Indonesia Nomor 2019).

b. Undang-Undang Nomor 10 tahun 1992 tentang Perkembangan Kependudukan dan Pembangunan Keluarga Sejahterah.

c. Undang-Undang Nomor 23 Tahun 2002 tentang Perlindungan Anak (Lembaran Negara Republik Indonesia Tahun 2002 Nomor 109, Tambahan Lembaran Negara Republik Indonesia Nomor 4235).

d. Undang-Undang Nomor 23 tahun 2004 tentang Penghapusan Kekerasan dalam Rumah Tangga (Lembaran Negara Republik Indonesia Tahun 2004 Nomor 95, Tambahan Lembaran Negara Republik Indonesia Nomor 4419).

e. Instruksi Presiden Nomor 9 Tahun Tahun 2000 tentang Pengarusutamaan Gender dalam Pembangunan Nasional.

f. Keputusan Presiden RI Nomor 88 Tahun 2002 tentang Rencana Aksi Nasional Penghapusan Perdagangan Perempuan dan Anak.

g. Peraturan Presiden Nomor 20 Tahun 2008 tentang Perubahan keempat Atas Peraturan Presiden Nomor 9 Tahun 2005 tentang Kedudukan, Tugas, Fungsi, Susunan Organisasi dan Tata Kerja Kementerian Negara Republik Indonesia.

h. Peraturan Presiden Nomor 24 Tahun 2006 tentang Kedudukan, Tugas dan Fungsi Kementerian Negara serta Susunan Organisasi, Tugas dan Fungsi Eselon I Kementerian Negara.

8 BP4 ialah lembaga yang mengatur tentang bagaimana menciptakan keluarga sakinah, mawaddah, dan rahmah. BP4 merupakan badan resmi yang diakui oleh pemerintah melalui Keputusan Menteri Agama Nomor 30 Tahun 1977 dan berkedudukan dibawah otoritas KUA Kecamatan. Lihat Lukman Khakim, Peran BP4 terhadap Efektifitas Kursus Pra Nikah dalam Mengarungi Terjadinya Perceraian (Studi pada BP4 Kecamatan Parung Kabupaten Bogor), Skripsi (Jakarta: UIN Syarif Hidayatullah, 2014), 15.

${ }^{9}$ Peraturan Direktur Jendral Bimbingan Masyarakat Islam No. DJ.II/542 Tahun 2013 Tentang Penyelenggaraan Kursus Pra-Nikah. 
i. Keputusan Menteri Agama Nomor 3 Tahun 1999 tentang Gerakan Keluarga Sakinah.

j. Keputusan Menteri Agama Nomor 480 Tahun 2008 tentang Perubahan Atas Keputusan Menteri Agama Nomor 373 Tahun 2002 tentang Organisasi dan Tata Kerja Kantor Wilayah Kementerian Agama Provinsi dan Kantor Departemen Agama Kabupaten/Kota.

k. Peraturan Menteri Agama Nomor 10 Tahun 2010 tentang Organisasi dan Tata Kerja Kementerian Agama.

1. Surat Edaran Menteri Dalam Negeri Nomor 400/54/III/Bangda perihal Pelaksanaan Pembinaan Gerakan Keluarga Sakinah.

m. Peraturan Direktur Jendral Bimbingan Masyarakat Islam No. DJ.II/542 Tahun 2013 Tentang Penyelenggaraan Kursus Pra-Nikah.

\section{Penyelenggara Kursus Pra-nikah}

Pedoman penyelenggaraan kursus pra-nikah dimaksudkan sebagai pedoman untuk para pejabat teknis di lingkungan Direktorat Jenderal Bimbingan Masyarakat Islam C.q Direktorat Urusan Agama Islam di tingkat Pusat, Provinsi, Kabupaten/Kota dan KUA Kecamatan serta badan/lembaga yang menyenggarakan kegiatan kursus pra-nikah. ${ }^{10}$ Pedoman penyelenggaraan kursus pra-nikah tertera dalam Peraturan Direktur Jendral Bimbingan Masyarakat Islam No. DJ.II/542 Tahun 2013 Tentang Penyelenggaraan Kursus Pra-Nikah.

Ketentuan Pasal 3 ayat (1) Peraturan Dirjen Masyarakat Islam Tahun 2013 tentang Penyelenggaraan Kursus Pra Nikah, bahwa penyelenggara kursus pra-nikah adalah Badan Penasihatan, Pembinaan, dan Pelestarian Perkawinan (BP4) atau lembaga/organisasi keagamaan Islam lainnya sebagai penyelenggara kursus pranikah yang telah mendapat Akreditasi dari Kementerian Agama. ${ }^{11}$ Dengan adanya ketentuan ini, maka penyelenggaraan kursus pra-nikah dapat dilaksanakan oleh lembaga/badan di luar instansi pemerintah, dalam hal ini adalah KUA kecamatan, tetapi pelaksanaannya dilakukan oleh badan/lembaga swasta yang telah memenuhi ketentuan yang ditetapkan oleh pemerintah. Pemerintah dalam hal ini Kementerian

\footnotetext{
${ }^{10}$ Badarudin, Bahan Ajaran Pelatihan Korps Penasihat BP-4 (Yogyakarta: Kementerian Agama, 2012), 3-4.

11 Lampiran Peraturan Direktur Jenderal Bimbingan Masyarakat Islam Kementerian Agama Nomor DJ.II/542 Tahun 2013 Tentang Pedoman Penyelenggaraan Kursus Pra-Nikah.
} 
Agama berfungsi sebagai regulator, pembina dan pengawas. Penyelenggaraan kursus pra-nikah sebagaimana diatur dalam pedoman ini dan memberi kesempatan yang luas kepada masyarakat untuk ikut serta mengurangi angka perceraian dan kekerasan dalam keluarga. ${ }^{12}$

\section{Penyelenggaraan Kursus Pra-Nikah}

Kursus pra-nikah atau pembekalan singkat (short course) ini diberikan kepada remaja usia nikah atau calon pengantin dengan waktu tertentu, yaitu selama 24 (dua puluh empat) jam pelajaran (JPL) selama 3 (tiga) hari atau dibuat beberapa kali pertemuan dengan JPL yang sama. Waktu pelaksanaan dapat disesuaikan dengan kesempatan yang dimiliki oleh peserta. ${ }^{13}$

Ada lima unsur yang perlu diperhatikan dalam penyelenggaraan kursus pranikah, yaitu sarana pembelajaran, materi dan metode pembelajaran, narasumber atau pengajar, biaya dan sertifikat. Unsur-unsur tersebut termaktub dalam Bab V Lampiran Peraturan Direktur Jenderal Bimbingan Masyarakat Islam Kementerian Agama Nomor DJ.II/542 Tahun 2013 Tentang Pedoman Penyelenggaraan Kursus Pra-Nikah. Penjelasan mengenai unsur tersebut, dapat dijelaskan sebagai berikut:

a. Sarana Pembelajaran

Sarana penyelenggaraan kursus pra-nikah meliputi sarana belajar mengajar, baik berupa silabus, modul dan bahan ajar lainya yang dibutuhkan untuk pembelajaran. Silabus dan modul disiapkan oleh Kementerian Agama untuk dijadikan acuan oleh penyelenggara kursus pra-nikah.

b. Materi dan Metode Pembelajaran

Materi kursus pra-nikah terdiri dari kelompok dasar, kelompok inti dan kelompok penunjang. Kelompok dasar meliputi kebijakan Kementerian Agama tentang pembinaan keluarga sakinah, kebijakan Ditjen Bimas Islam tentang pelaksanaan kursus pra-nikah, peraturan perundangan tentang perkawinan dan pembinaan keluarga, hukum munakahat, dan prosedur pernikahan. Kelompok Inti meliputi pelaksanaan fungsi-fungsi keluarga, merawat cinta kasih dalam keluarga, manajemen konflik dalam keluarga, dan psikologi perkawinan dan keluarga. Sedangkan kelompok penunjang meliputi pendekatan andragogi,

12 Badarudin, Modul..., 7.

13 Ibid. 
penyusunan SAP (satuan acara pembelajaran) dan micro teaching, pre-test dan post test dan penugasan atau rencana aksi. ${ }^{14}$

Materi-materi yang telah disebutkan dalam kurikulum dan silabus di atas, dapat diberikan dengan metode ceramah, diskusi, tanya-jawab, studi kasus (simulasi) dan penugasan yang pelaksanaannya dapat disesuaikan dengan kondisi dan kebutuhan di lapangan.

c. Narasumber/Pengajar

Narasumber arau pengajar yang memberikan materi kepada para calon pengantin dapat dari kalangan konsultan keluarga, tokoh agama, psikolog, dan yang terpenting adalah harus professional di bidangnya.

d. Pembiayaan

Pembiayaan kursus pra-nikah sesuai ketentuan Pasal 5 dapat bersumber dari dana APBN, APBD, dan sumber lain yang halal dan tidak mengikat. Dana pemerintah berupa APBN atau APBD bisa diberikan kepada penyelenggara dalam bentuk bantuan, bantuan kepada badan/lembaga swasta dari dana APBN atau APBD. Selain sumber dana tersebut dapat pula dari iuran peserta atau bantuan dari masyarakat yang halal dan tidak mengikat serta mempunyai komitmen kuat untuk membantu berpartisipasi dalam pembinaan keluarga. ${ }^{15}$

e. Sertifikasi

Sertifikasi adalah pernyataan resmi yang dikeluarkan oleh lembaga yang berkompeten yang telah diakreditasi oleh Kementerian Agama bahwa yang bersangkutan telah mengikuti kegiatan kursus pra-nikah. Sertifikasi disiapkan oleh organisasi lembaga, atau badan yang menyelenggarakan kursus pra-nikah (Pasal 6 ayat 1,2 dan 3). ${ }^{16}$

14 Untuk lebih jelasnya dapat dilihat pada kurikulum dan silabus kursus pra-nikah dalam Lampiran Peraturan Direktur Jenderal Bimbingan Masyarakat Islam Kementerian Agama Nomor DJ.II/542 Tahun 2013 Tentang Pedoman Penyelenggaraan Kursus Pra-Nikah.

15 Lampiran Peraturan Direktur Jenderal Bimbingan Masyarakat Islam Kementerian Agama Nomor DJ.II/542 Tahun 2013 Tentang Pedoman Penyelenggaraan Kursus Pra-Nikah.

${ }^{16}$ Peraturan Direktur Jenderal Bimbingan Masyarakat Islam No. DJ.II/542 Tahun 2013 tentang Pedoman Penyelenggaraan Kursus Pranikah, Bab III, Bagian Keempat Pasal 6 Ayat (1): Remaja usia nikah yang telah mengikuti kursus pranikah diberikan sertifikat sebagai tanda bukti kelulusan, Ayat (2): Sertifikat sebagaimana dimaksud pada ayat (1) dikeluarkan oleh BP4 atau organisasi keagamaan Islam penyelenggara kursus. Ayat (3) Sertifikat sebagaimana dimaksud pada ayat (1) dapat menjadi syarat kelengkapan pencatatan perkawinan. 
Sertifikat tersebut diberikan kepada peserta kursus sebagai tanda kelulusan atau sebagai bukti yang bersangkutan telah mengikuti kursus pra-nikah. Calon pengantin yang telah mengikuti kursus pra-nikah diberikan sertifikat sebagai tanda bukti kelulusan. Sertifikat tersebut akan menjadi syarat perlengkapan pencatatan perkawinan, yaitu pada saat mendaftar di KUA. Walaupun dokumen sertifikat ini sifatnya tidak wajib, tetapi sangat dianjurkan memilikinya, karena dengan memiliki sertifikat berarti pasangan pengantin sudah mempunyai bekal pengetahuan tentang membangun rumah tangga. ${ }^{17}$

\section{Kursus Pra-Nikah di KUA Kec. Pontianak Timur}

Pelaksanaan kursus pra-nikah atau yang lebih dikenal dengan Suscatin, dilaksanakan secara rutin seminggu satu kali, yaitu setiap hari rabu, dari jam 09.00 WIB sampai jam 11.00 WIB. Penyuluh fungsional KUA merangkup juga sebagai narasumber memberikan pembekalan atau arahan kepada peserta Suscatin (calon pasangan suamiisteri) mengenai apa yang harus dipersiapkan ketika berumah tangga. Arahan atau pembekalan tersebut diberikan dengan metode ceramah dan diselingi dengan canda dan tawa, kemudian di sesi akhir menggunakan metode tanya-jawab langsung dengan peserta Suscatin tersebut. $^{18}$

Sepuluh hari sebelum dilaksanakannya suscatin tersebut, pertama calon pasangan suami isteri tersebut harus melengkapi syarat-syarat nikah yang diberikan oleh pegawai KUA Kecamatan Pontianak Timur. Setelah persyaratannya lengkap, kemudian dari pihak KUA memberikan blanko pendaftaran Suscatin, yang kemudian blanko tersebut dibawa katika hendak mengikuti kursus pra-nikah tersebut. Apabila sudah lengkap, barulah calon pasangan suami isteri tersebut dapat mengikuti suscatin tersebut.

Menurut hemat penulis, ada perbedaan yang mendasar mengenai pelaksanaan teknis Suscatin di KUA Kecamatan Pontianak Timur dengan Peraturan Jenderal Bimbingan Masyarakat Islam Kementerian Agama Nomor DJ.II/542 Tahun 2013 Tentang Pedoman Penyelenggaraan Kursus Pra-Nikah. Dalam Pasal 9 ayat (4) dinyatakan, bahwa materi kursus pra-nikah diberikan sekurang-kurangnya 16 jam pelajaran. Sedangkan dalam pelaksanannya di KUA Kecamatan Pontianak Timur hanya

${ }^{17}$ Badarudin, Modul..., 12.

${ }^{18}$ Data diperoleh dari hasil observasi di KUA Kecamatan Pontianak Timur pada tanggal 26 Januari 2015. 
dilaksanakan selama 3 jam, yaitu dari jam 09.00 WIB sampai dengan jam 11.00 WIB yang dilakukan setiap hari rabu.

\section{Materi dan Metode Kursus Pra-Nikah}

Kurikulum dan silabus kursus pra-nikah yang tertera dalam Lampiran Peraturan Direktur Jenderal Bimbingan Masyarakat Islam Kementerian Agama Nomor DJ.II/542 Tahun 2013 Tentang Pedoman Penyelenggaraan Kursus PraNikah, materi kursus pra-nikah terdiri dari kelompok dasar, kelompok inti dan kelompok penunjang. Kelompok dasar meliputi kebijakan Kementerian Agama tentang pembinaan keluarga sakinah, kebijakan Ditjen Bimas Islam tentang pelaksanaan kursus pra-nikah, peraturan perundangan tentang perkawinan dan pembinaan keluarga, hukum munakahat, dan prosedur pernikahan. Kelompok Inti meliputi pelaksanaan fungsi-fungsi keluarga, merawat cinta kasih dalam keluarga, manajemen konflik dalam keluarga, dan psikologi perkawinan dan keluarga. Sedangkan kelompok penunjang meliputi pendekatan andragogi, penyusunan SAP (satuan acara pembelajaran) dan micro teaching, pre-test dan post test dan penugasan atau rencana aksi. ${ }^{19}$

Sedangkan materi-materi yang disampaikan oleh Penghulu Fungsional KUA Kecamatan Pontianak Timur secara garis besar ada empat. Pertama, wawasan rumah tangga yang membahas tentang pemecahan masalah rumah tangga dan akhlak, baik tentang perilaku, ucapan maupun karakter. Kedua, pendidikan rencana rumah tangga, meliputi thaharah, ibadah dan imam sholat. Ketiga, waktu dan tata cara akad nikah. Pembahasan ini meliputi disimplin waktu penghulu, tata cara akad nikah dan pentingnya wali nikah. Keempat adalah manajemen ekonomi yang meliputi prioritas utama dalam rumah tangga (beras), persoalan penghasilan dan cara memahami pekerjaan masing-masing. Dari keempat materi pokok tersebut, dapat diambil garis besarnya yaitu manajemen rumah tangga. ${ }^{20}$

Materi-materi yang telah dijelaskan di atas, disampaikan oleh pemateri (narasumber) dengan metode ceramah, metode tanya-jawab, metode interaktif, lebih tepatnya adalah metode kombinasi. Hal ini senada apa yang disampaikan oleh

19 Untuk lebih jelasnya dapat dilihat pada kurikulum dan silabus kursus pra-nikah dalam Lampiran Peraturan Direktur Jenderal Bimbingan Masyarakat Islam Kementerian Agama Nomor DJ.II/542 Tahun 2013 Tentang Pedoman Penyelenggaraan Kursus Pra-Nikah.

${ }^{20}$ Data diperoleh dari hasil interview dengan Penghulu Fungsional KUA Kecamatan Pontianak Timur bernama M. Dani, S.Ag., tertanggal 26 Januari 2015. 
Muhammad Dani, “Kita biasanya interaktif juga, lebih tepatnya kombinasi. Metode-metode yang saya gunakan baik itu metode ceramah, metode tanya-jawab, jadi kombinasi semuanya. Jadi yang mana kira-kira audiennya itu, kita kan bisa melihat arahnya ke mana? Yang mana kita fokuskkan? Dominasinya di mana? Kira-kira audiennya memang orang-orang yang mengerti agama, kita agak kendor di hal itu, kita mengarah ke hal yang lain, sesuai dengan modulnya tadi."21

Apabila kita bandingkan materi dan metode kursus pra-nikah di KUA Kecamatan Pontianak Timur dengan kurikulum dan silabus kursus pra-nikah yang tertera dalam Lampiran Peraturan Direktur Jenderal Bimbingan Masyarakat Islam Kementerian Agama Nomor DJ.II/542 Tahun 2013 Tentang Pedoman Penyelenggaraan Kursus Pra-Nikah, banyak sekali materi yang belum disampaiakan oleh penghulu fungsional KUA Kecamatan Pontianak Timur. Di antaranya adalah kebijakan Kementerian Agama tentang pembinaan keluarga sakinah, kebijakan Ditjen Bimas Islam tentang pelaksanaan kursus pra-nikah, peraturan perundangan tentang perkawinan dan pembinaan keluarga, psikologi perkawinan dan keluarga, fungsi-fungsi keluarga, dan merawat cinta kasih dalam keluarga.

\section{Pemateri dan Peserta Kursus Pra-Nikah}

Mempersiapkan para calon suami-isteri untuk memasuki kehidupan berumah tangga dengan dibekali sejumlah pengetahuan, informasi, pemahaman, masukan ataupun pencerahan yang berkaitan dengan kehidupan berumah tangga, merupakan salah satu tujuan dari diadakannya kursus pra-nikah. Untuk mencapai tujuan tersebut, dibutuhkan kemampuan dan keahlian sesorang pemateri atau penasehat dalam menyampaikan materi-materi yang disampaikan ketika Suscatin. Apabila yang menjadi pemateri bukan orang yang ahli, maka kursus pra-nikah tidak akan membuahkan hasil yang maksimal, yakni membentuk sebuah keluarga yang sakinah.

Pemateri atau narasumber Suscatin di KUA Kecamatan Pontianak Timur adalah orang yang mempunyai banyak pengalaman dan kompetensi di bidangnya. Dalam hal ini langsung diberikan kepada Penghulu Fungsional yang bekerja di

${ }^{21}$ Data diperoleh dari hasil interview dengan Penghulu Fungsional KUA Kecamatan Pontianak Timur bernama M. Dani, S.Ag., tertanggal 26 Januari 2015. 
KUA Kecamatan Pontianak Timur tersebut. Penghulu Fungsional yang bekerja di KUA Kecamatan Pontianak Timur adalah Muhammad Dani. Ia adalah seorang Penghulu Fungsional di KUA Kecamatan Pontianak Timur. Ia telah mengabdi di Kementerian Agama sejak tanggal 01 April 2006, sedangkan mulai bekerjadi di KUA Kecamatan Pontianak Timur pada tanggal 01 Januari 2011.

Apabila kita bandingkan dengan panduan kursus pra-nikah tahun 2013, narasumber arau pengajar yang memberikan materi kepada para calon pengantin dapat dari kalangan konsultan keluarga, tokoh agama, psikolog, dan yang terpenting adalah harus professional di bidangnya. Sedangkan di KUA Kecamatan Pontianak Timur, semua materi sampaikan oleh seorang penghulu fungsional.

Adapun peserta kursus pra-nikah di KUA Kecamatan Pontianak Timur adalah pasangan calon suami-isteri yang telah melengkapi syarat-syarat nikah dan mengisi blanko pendaftaran Suscatin. ${ }^{22}$ Ketentuan mengenai peserta kursus pra-nikah ini juga tertera pada Pasal 7 Peraturan Direktur Jenderal Bimbingan Masyarakat Islam Kementerian Agama Nomor DJ.II/542 Tahun 2013 Tentang Pedoman Penyelenggaraan Kursus Pra-Nikah, "Peserta kursus pra-nikah adalah remaja usia nikah ${ }^{23}$ dan calon pengantin yang akan melangsungkan perkawinan.”

\section{Sertifikat dan Pembiyaan Kursus Pra-Nikah}

Setelah pasangan calon suami-isteri mengikuti Suscatin, kemudian BP4 membuat sertifikat sebagai bukti bahwa pasangan tersebut telah mengikuti Suscatin tersebut. Sertifikat tersebut akan menjadi syarat perlengkapan pencatatan perkawinan, yaitu pada saat mendaftar di KUA. Walaupun dokumen sertifikat ini sifatnya tidak wajib, tetapi sangat dianjurkan memilikinya, karena dengan memiliki sertifikat berarti pasangan pengantin sudah mempunyai bekal pengetahuan tentang membangun rumah tangga dan berupaya mempersiapkan diri secara matang untuk mengarungi kehidupan baru, yaitu dengan membekali dirinya dengan pengetahuan dan pemahaman tentang seluk-beluk kerumahtanggaan, sehingga apapun goncangan yang mereka hadapi nantinya akan diantisipasi secara baik, karena sudah dibekali rambu-rambunya. Januari 2015.

22 Data diperoleh dari hasil observasi di KUA Kecamatan Pontianak Timur pada tanggal 26

${ }^{23}$ Remaja usia nikah adalah laki-laki muslim berumur sekurang-kurangnya 19 tahun dan perempuan muslimah 16 tahun. 
Mengenai pembiayaan kursus pra-nikah ini sesuai ketentuan Pasal 5 Peraturan Direktur Jenderal Bimbingan Masyarakat Islam Kementerian Agama Nomor DJ.II/542 Tahun 2013 Tentang Pedoman Penyelenggaraan Kursus Pra-Nikah, dapat bersumber dari dana APBN, APBD, dan sumber lain yang halal dan tidak mengikat. Selain sumber dana tersebut dapat pula dari iuran peserta atau bantuan dari masyarakat yang halal dan tidak mengikat serta mempunyai komitmen kuat untuk membantu berpartisipasi dalam pembinaan keluarga. ${ }^{24}$

\section{Konseling Pra-Nikah di GKKB Jemaat Pontianak}

GKKB Jemaat Pontianak berprinsip untuk mempermudah pasangan dalam mengikuti konseling pra-nikah. Pasangan yang akan mengikuti konseling pra-nikah cukup mendaftarkan namanya ke gereja, kemudian gereja akan menghubungi pasangan tersebut jika pelaksanaan konseling pra-nikah telah siap dilaksanakan. Pasangan yang akan mengikuti konseling pra-nikah pun tidak dikenai biaya apapun, hanya diharuskan mengganti uang photo copy modul materi konseling pra-nikah sebesar $12.500,00 .{ }^{25}$

Apabila pasangan yang telah mendaftarkan diri untuk mengikuti konseling pranikah telah dihubungi oleh gereja, pasangan tersebut bisa langsung datang pada waktu yang telah ditentukan. GKKB Jemaat Pontianak melaksanakan konseling pra-nikah setiap bulan Februari dan Agustus pada setiap tahunnya. Pasangan yang akan melaksanakan pemberkatan pada bulan September, Oktober, November, Desember, Januari dan Februari bisa mengikuti konseling pra-nikah pada bulan Februari. Sedangkan pasangan yang akan melaksanakan pemberkatan pada bulan Maret, April, Mei, Juni, Juli dan Agustus bisa mengikuti konseling pra-nikah pada bulan Agustus. ${ }^{26}$

\section{Materi dan metode Konseling Pra-Nikah}

Konseling pra-nikah di GKKB Jemaat Pontianak dilaksanakan selama tujuh sesi (pertemuan) yang setiap sesi durasi waktunya \pm 2 jam. Jadwal tersebut ditentukan oleh gereja berdasarkan kesiapan waktu konselor. Pasangan yang mengikuti konseling pra-nikah akan diabsensi. Bagi pasangan yang berhalangan

\footnotetext{
${ }^{24}$ Lampiran Peraturan Direktur Jenderal Bimbingan Masyarakat Islam Kementerian Agama Nomor DJ.II/542 Tahun 2013 Tentang Pedoman Penyelenggaraan Kursus Pra-Nikah.

${ }^{25}$ Interview dengan Jhoni Wang, salah seorang penginjil di GKKB Jemaat Pontianak, tertanggal 28 Januari 2015.

${ }^{26}$ Interview dengan Jhoni Wang, salah seorang penginjil di GKKB Jemaat Pontianak, tertanggal 28 Januari 2015.
} 
hadir pada sesi tertentu, akan diberikan konseling secara khusus di ruangan tertentu oleh konselor yang telah ditunjuk oleh gereja. Tujuannya adalah supaya pasangan tersebut bisa mendapatkan semua materi yang telah diwajibkan.

Selama tujuh sesi (pertemuan) yang diikuti oleh pasangan yang mengikuti konseling pra-nikah, para konseli akan mendapatkan delapan materi konseling. Setiap materi tersebut tidak selalu dilaksanakan secara berurutan, tergantung pada kesiapan waktu dari konselor. Adapun delapan materi konseling tersebut, yaitu Meletakkan Dasar, Mencari Allah bersama, Memahami Peran dan Pengharapan Kita, Membangun Sistem Komunikasi, Keputusan dan Menghilangkan Konflik, Menghadapi Mertua, Menghargai Berkat Seksual dari Allah, dan Keluarga Berencana (KB).

Di GKKB Jemaat Pontianak, konseling pra-nikah dilaksanakan di sebuah ruangan khusus. Di ruangan itulah seluruh peserta akan mendapatkan materi konseling pra-nikah. Selain metode ceramah dan dialogis, konseling pra-nikah di GKKB Jemaat Pontianak dilakukan dengan metode role-playing, diantaranya masing-masing pasangan harus mengisi pertanyaan-pertanyaan yang telah disediakan pada diktat konseling pernikahan, dan jawaban dari setiap pasangan tersebut akan dicocokkan dengan jawaban pasangan lainnya. Dengan metode tersebut, suasana dalam konseling pra-nikah di GKKB Jemaat Pontianak menjadi lebih hidup karena yang aktif bukan hanya konselor, namun juga para konseli.

\section{Pemateri dan Peserta Konseling Pra-Nikah}

Sebagai sebuah gereja yang besar, GKKB Jemaat Pontianak mempunyai banyak konselor yang bisa menyampaikan materi konseling pra-nikah. Syarat untuk menjadi konselor pada konseling pra-nikah di GKKB Jemaat Pontianak adalah harus Pendeta dan atau Penginjil yang telah menikah lebih dari lima tahun. Persyaratan konselor menikah lebih dari lima tahun ini agar konselor bisa menceritakan dan menyampaikan pengalaman hidupnya dalam membangun rumah tangga serta pengalaman hidupnya dalam memecahkan masalah rumah tangga. Pengalaman itu tentu tidak akan bisa disampaikan jika konselor belum menikah.

Peserta konseling pra-nikah yang dilaksanakan pada bulan Februari dan Agustus di GKKB Jemaat Pontianak jumlahnya berbeda-beda pada setiap tahunnya. Namun, sebagaimana dikatakan oleh Jhoni Wang, saat dirinya menjadi konselor 
dalam lima tahun terakhir ini, peserta konseling pra-nikah yang paling banyak adalah berjumlah 25 pasang. Pasangan yang akan menjadi peserta konseling pranikah adalah jamaat yang telah terdaftar di GKKB Jemaat Pontianak. Jika salah satu pihak dari pasangan itu bukan termasuk dari jamaat GKKB Jemaat Pontianak, pihak tersebut boleh mengikuti konseling pra-nikah di GKKB Jemaat Pontianak dan GKKB Jemaat Pontianak akan bisa melaksanakan pemberkatan bagi pasangan tersebut. Namun, jika konseling pra-nikah mengikuti dari gereja selain GKKB Jemaat Pontianak, maka GKKB Jemaat Pontianak tidak akan melaksanakan pemberkatan hingga pihak tersebut meminta surat keterangan bahwa telah pernah mengikuti konseling pra-nikah dari gereja tersebut. Hal ini perlu dilakukan untuk memastikan bahwa semua jamaat yang akan melaksanakan pemberkatan harus mengikuti konseling pra-nikah. ${ }^{27}$

\section{Sertifikat dan Pembiyaan Konseling Pra-Nikah}

Konseling pra-nikah di GKKB Jemaat Pontianak akan berakhir jika telah dilaksanakan tujuh kali pertemuan dengan delapan materi konseling. GKKB Jemaat Pontianak merasa tidak perlu memberikan sertifikat atau bukti bahwa pasangan telah melaksanakan konseling pra-nikah karena peserta yang mengikuti konseling adalah memang jamaat GKKB Jemaat Pontianak dan telah tersistem dalam database gereja. Sehingga jamaat yang akan melaksanakan pemberkatan nanti akan dicek biodatanya di database gereja, apakah telah mengikuti konseling pra-nikah. Jika belum mengikuti,, maka GKKB Jemaat Pontianak tidak akan melakukan pemberkatan, dan memerintahkan jamaat tersebut untuk mengikuti konseling pranikah terlebih dahulu. ${ }^{28}$ Kecuali GKKB Jemaat Pontianak akan memberikan atau mengeluarkan surat keterangan telah mengikuti konseling pra-nikah, khusus bagi jamaat yang akan melaksanakan pemberkatan di gereja lain. Oleh sebab itulah, antar gereja akan selalu terjalin komunikasi dalam rangka memberikan pelayanan yang baik bagi para jamaat.

${ }^{27}$ Interview dengan salah seorang penginjil di GKKB Jemaat Pontianak bernama Jhoni Wang, tertanggal 28 Januari 2015.

${ }^{28}$ Interview salah seorang Penginjil di GKKB Jemaat Pontianak bernama Jhoni Wang, tertanggal 28 Januari 2015. 


\section{Persamaan dan Perbedaan Pelaksanaan Kursus Pra-Nikah di KUA Kec. Pontianak Timur dengan Konseling Pra-Nikah di GKKB Jemaat Pontianak}

Berdasarkan paparan data yang telah dijelaskan sebelumnya, terdapat perbedaan dan persamaan pelaksanaan kursus pra-nikah yang dilaksanakan oleh KUA Kec. Pontianak Timur dan GKKB Jemaat Pontianak. Perbedaan dan persamaan dalam kursus pra-nikah ini sama-sama dilatarbelakangi oleh perubahan sosial yang membutuhkan persiapan yang ekstra dalam mempersiapkan pernikahan, atau terkesan terburu-buru. Tujuannya adalah untuk memberikan gambaran kepada pasangan calon suami-isteri akan hal-hal yang dihadapi dalam sebuah perkawinan, sehingga mereka tidak kaget dalam menjalaninya.

Di sini, penulis memaparkan secara garis besar perbedaan dan persamaan pelaksanaan kursus pra-nikah yang dilaksanakan oleh KUA Kec. Pontianak Timur dan GKKB Jemaat Pontianak. Hal tersebut dapat dilihat sebagai berikut ini:

\section{Tabel 2}

Persamaan dan Perbedaan Pelaksanaan Kursus Pra-Nikah di KUA Kec.

Pontianak Timur dengan Di GKKB Jemaat Pontianak

\begin{tabular}{|c|c|c|c|}
\hline No. & Kategori & KUA Kec. Pontianak Timur & GKKB Jamaat Pontianak \\
\hline 1. & Istilah & Kursus calon pengantin (Suscatin). & Konseling pra-nikah. \\
\hline 2. & Persyaratan & $\begin{array}{l}\text { Syarat-syarat nikah dan mengisi } \\
\text { blanko Suscatin. }\end{array}$ & $\begin{array}{l}\text { Tidak ada ketentuan dan syarat- } \\
\text { syarat yang harus dipenuhi oleh } \\
\text { pasangan yang akan mengikuti } \\
\text { konseling pra-nikah. }\end{array}$ \\
\hline 3. & Pelaksanaan & $\begin{array}{l}\text { Dilaksanakan setiap hari } \\
\text { (seminggu sekali) dari jam } 09.00 \\
\text { WIB sampai jam } 11.00 \text { WIB. }\end{array}$ & $\begin{array}{l}\text { Dilaksanakan dua kali setiap satu } \\
\text { tahun, yaitu bulan Februari dan } \\
\text { Agustus. Tujuh kali pertemuan } \\
\text { dengan delapan materi konseling. }\end{array}$ \\
\hline 4. & Materi & $\begin{array}{l}\text { Manajemen ekonomi, wawasan } \\
\text { rumah tangga, pendidikan rencana } \\
\text { rumah tangga, meliputi thaharah, } \\
\text { ibadah dan imam sholat, waktu dan } \\
\text { tata cara akad nikah. }\end{array}$ & $\begin{array}{l}\text { Meletakkan dasar, mencari Allah } \\
\text { bersama, memahami peran dan } \\
\text { pengharapan kita, membangun } \\
\text { sistem komunikasi, membuat } \\
\text { keputusan dan menghilangkan } \\
\text { konflik, menghadapi mertua, } \\
\text { menghargai berkat seksual dari } \\
\text { Allah, keluarga berencana (KB). }\end{array}$ \\
\hline 5. & Metode & $\begin{array}{l}\text { Metode ceramah, tanya-jawab, dan } \\
\text { metode interaktif. }\end{array}$ & $\begin{array}{l}\text { Metode ceramah, dialogis, dan } \\
\text { role-playing. }\end{array}$ \\
\hline 6. & Pemateri & $\begin{array}{l}\text { Penghulu Fungsional yang bekerja } \\
\text { di KUA Kecamatan Pontianak } \\
\text { Timur. }\end{array}$ & $\begin{array}{l}\text { Pendeta dan atau Penginjil yang } \\
\text { telah menikah lebih dari lima } \\
\text { tahun. }\end{array}$ \\
\hline 7. & Peserta & Calon pasangan pengantin yang & Jamaat yang terdaftar di GKKB \\
\hline
\end{tabular}




\begin{tabular}{|c|l|l|l|}
\hline & & $\begin{array}{l}\text { telah mendaftarkan diri dan } \\
\text { memenuhi persyaratan administrasi. }\end{array}$ & $\begin{array}{l}\text { Jemaat Pontianak dan ingin } \\
\text { melaksanakan pemberkatan. }\end{array}$ \\
\hline 8. & Sertifikat & $\begin{array}{l}\text { Setelah pasangan mengikuti } \\
\text { Suscatin, BP4 membuat sertifikat } \\
\text { sebagai bukti bahwa pasangan } \\
\text { tersebut telah mengikuti Suscatin. }\end{array}$ & $\begin{array}{l}\text { Tidak menggunakan sertifikat, } \\
\text { tetapi sudah tersistem dalam } \\
\text { database gereja. }\end{array}$ \\
\hline 9. & Pembiayaan & Gratis & Gratis \\
\hline 10. & Follow up & Tidak ada & Tidak ada \\
\hline
\end{tabular}

Dilihat dari persyaratannya, persyaratan mengikuti Suscatin di KUA Kec.

Pontianak Timur berbeda dengan persyaratan konseling pra-nikah di GKKB Jemaat Pontianak. Persyaratan kursus pra-nikah di GKKB Jemaat Pontianak lebih mudah dan tidak ribet dari pada di KUA Kec. Pontianak Timur. Hal ini dikarenakan, secara pengelolaan administrasi keduanya berbeda. GKKB Jemaat Pontianak telah mempunyai data base jamaat, sehingga pasangan yang ingin mengikuti konseling pra-nikah cukup mengajukan namanya, dan dapat langsung mengakses ke data base mengenai profil lengkap jamaat tersebut. Sedangkan di KUA Kec. Pontianak Timur tidak mempunyai data base masyarakat yang berada dibawah pemerintahannya, sehingga sangat wajar apabila dalam proses pendaftaran kursus pra-nikah di KUA Kec. Pontianak Timur dibutuhkan data-data yang lebih lengkap dan lebih banyak.

Dalam pelaksanaan kursus pra-nikah, konseling pra-nikah GKKB Jemaat Pontianak lebih efektif jika dibandingkan dengan Suscatin KUA Kec. Pontianak Timur. Konseling pra-nikah di GKKB Jemaat Pontianak dilaksanakan selama tujuh sesi (pertemuan) yang setiap sesi durasi waktunya \pm 2 jam (14 jam). Konseling pra-nikah ini dilaksanakan setahun hanya dua kali, yaitu pada bulan Februari dan Agustus. Sedangkan Suscatin di KUA Kec. Pontianak Timur dilaksanakan setiap seminggu sekali hanya dalam satu sesi, yaitu setiap hari rabu jam 09.00 WIB - 11.00 WIB. Menurut hemat penulis, perbedaan ini dipengaruhi oleh banyaknya peserta kursus Suscatin di KUA Kec. Pontianak Timur dibandingkan dengan peserta konseling pra-nikah GKKB Jemaat Pontianak.

Materi konseling pra-nikah di GKKB Jemaat Pontianak dan Suscatin di KUA Kec. Pontianak Timur sama-sama menekankan pentingnya meningkatkan keimanan dalam rangka membangun rumah tangga yang sakinah. Perbedaannya lebih spesifik pada materi yang disampaikan. Materi-materi yang disampaikan ketika Suscatin di KUA Kec. Pontianak Timur lebih menekankan pada management ekonomi dalam berumah tangga. Hal ini dianggap penting, karena hal yang paling banyak menyebabkan 
rusaknya bangunan rumah tangga adalah karena faktor ekonomi. Berbeda dengan konseling pra-nikah di GKKB Jemaat Pontianak yang banyak menekankan pentingnya komunikasi dalam berumah tangga. Banyaknya konflik yang timbul antar suami isteri diawali oleh kesalahan dalam menjalin komunikasi.

Metode yang digunakan dalam Suscatin di KUA Kec. Pontianak Timur dan konseling pra-nikah di GKKB Jemaat Pontianak sama-sama menekankan komunikasi dua arah antara konselor dan konseli. Suatu komunikasi akan berjalan efektif dalam sebuah aktivitas dengan menggunakan komunikasi dua arah. Dengan metode tersebut, pasangan yang mengikuti kursus pra-nikah atau konseling pra-nikah selalu fokus pada pembicaraan yang sedang dilakukan. Manakala kedua pihak saling fokus pada pembicaraan, maka tujuan yang diinginkan akan mudah dicapai.

Peserta konseling pra-nikah di GKKB Jemaat Pontianak dan suscatin di KUA Kec. Pontianak Timur ialah sama-sama calon pasangan pengantin ingin melaksanakan perkawinan. Bedanya, peserta yang telah mengikuti konseling pra-nikah di GKKB Jemaat Pontianak hanya dilakukan sekali saja, karena ciri hakiki dalam perkawinan Kristen adalah tak terceraikan (unitas et indissolubilitas). Sedangkan peserta Suscatin di KUA Kec. Pontianak Timur adalah calon pasangan pengantin ingin melaksanakan perkawinan, baik ia duda atau janda.

Pemateri yang memberikan kursus atau konseling haruslah orang yang mampu menguasai materi-materi yang disampaikan. Hal yang tak kalah penting dari itu ialah pemateri haruslah orang yang telah menempuh rumah tangga. Atas latar belakang itulah, di GKKB Jemaat Pontianak mengharuskan pendeta atau penginjil yang boleh menjadi pemateri dalam konseling pra-nikah haruslah orang yang telah berumah tangga. Begitupula pada KUA Kec. Pontianak Timur, Penghulu Fungsional yang diberikan tugas sebagai pemateri adalah orang yang telah berumah tangga dan tentu saja dengan jabatan sebagai Penghulu Fungsional bisa dijadikan jaminan bahwa orang tersebut adalah orang yang mampu menguasai dan menyampaikan materi kursus dengan baik.

Menurut hemat penulis, pemateri seharusnya adalah orang yang berkopeten dan ahli dalam menyampaikan materi-materi yang disampaikannya. Apabila yang menjadi pemateri bukan orang yang ahli, maka kursus pra-nikah tidak akan membuahkan hasil yang maksimal, yakni membentuk sebuah keluarga yang sakinah. Oleh karena itu, apabila materi yang disampai ketika kursus pra-nikah mengenai psikologi keluarga 
(misalnya), maka pemateri atau konselor harus dari kalangan psikolog. Begitu juga apabila yang dibahas tentang menagemen ekonomi, maka pemateri atau konselor harus dari kalangan ekonomi. Jangan sampai penghulu fungsional atau pendeta atau penginjil yang menyampaikannya (materi psikologi keluarga, managemen ekonomi, dll), karena keahlian mereka adalah dalam hal norma-norma agama.

Setelah calon pasangan suami-isteri tersebut telah mengikuti kursus pra-nikah, maka BP4 KUA Kec. Pontianak Timur membuat sertifikat sebagai bukti bahwa pasangan tersebut telah mengikuti Suscatin. Sedangkan di GKKB Jemaat Pontianak tidak perlu sertifikat untuk membuktikan bahwa calon pasangan suami-isteri tersebut telah mengikuti kursus pra-nikah, melainkan hanya dengan menyetorkan nama saja. Hal ini dikarenakan, peserta yang telah mengikuti konseling pra-nikah di GKKB Jemaat Pontianak telah tersistem dalam database gereja. Apabila ia telah mengikuti konseling pra-nikah, maka namanya dalam database GKKB Jemaat Pontianak sudah terdaftar sebagai peserta yang telah mengikuti konseling pra-nikah tersebut.

Terlepas dari semua yang telah dijelaskan di atas, kursus pra-nikah adalah rangkaian kegiatan yang sangat dibutuhkan oleh calon pasangan suami-isteri sebelum melakukan pernikahan. Hal itu dikarenakan, perkawinan adalah ikatan yang suci dan sacral. Oleh karena itu, sebelum melaksanakanya, diperluakan persiapan, bimbingan, arahan, dan gambaran mengenai apa yang hendak dipersiapkan dan dibutuhkan untuk membangun rumah tangga yang sakinah.

\section{Penutup}

Perbedaan pelaksanaan kursus pra-nikah antara KUA Kecamatan Pontianak Timur dengan GKKB Jemaat Pontianak terletak pada istilah yang digunakan pada instansi masing-masing, persyaratannya, pelaksanaannya, pesertanya, materi yang disampaikan, pemateri dan metode yang digunakan, serta bukti telah mengikuti kursus pra-nikah tersebut. Sedangkan persamaan pelaksanaan kursus pra-nikah antara KUA Kecamatan Pontianak Timur dengan GKKB Jemaat Pontianak terdapat pada tujuannya, yaitu memberi arahan, gambaran persiapan, bimbingan, dan konseling kepada calon pasangan suami-isteri untuk dapat membina rumah tangga yang sakinah, mawaddah, dan rahmah. 


\section{Daftar Pustaka}

Amidhan, Syamsudin, dkk, Pertumbuhan dan Perkembangan BP4, Jakarta: Badan Penasehat Perkawinan, Perselisihan dan Perceraian, 1977.

Amini, Ibrahim, Bimbingan Islam Untuk Kehidupan Suami-Istri,cet. ke-10, Bandung: Al-Bayan, 1996.

Azhari, Ari, "Pelaksanaan Kursus Pra-Nikah (Studi Komperatif Di Kantor Urusan Agama Kec. Gondokusuman Kota Yogyakarta Dengan Lembaga Pembinaan Persiapan Hidup Bekeluarga Kevikepan DIY, Tesis tidak diterbitkan, Pascasarjana UIN sunan Kalijaga 2014.

Azwar, Saifuddin, Metode Penelitian, Yogyakarta: Pustaka Pelajar, 1998.

Badaruddin, Petunjuk Teknis Penyelenggaraan Kursus Pra-Nikah; Modul Kursus PraNikah, Yogyakarta: Seksi Urusan Agama Islam, 2012.

Bahan Ajaran Pelatihan Korps Penasihat BP-4, Yogyakarta: Kementerian Agama, 2012.

Bajuri, Azzuhri, "Peran Konseling dalam Penyelesaian Konflik Keluarga (Integrasi Konsep Konseling Keluarga Gestalt ke dalam Konsep Mediasi Hukum Keluarga Islan)”, Tesis tidak diterbitkan, Yogyakarta: Hukum Islam Konsentrasi Hukum Keluarga, 2013.

Baroroh, Nurdhin, "Fungsi dan Peran Badan Penasehatan Pembinaan dan Pelestarian Perkawinan (BP4) (Studi Kasus Kantor Urusan Agama Kecamatan Piyungan Kabupaten Bantul)”, Tesis tidak diterbitkan, Yogyakarta: Hukum Islam Konsentrasi Hukum Keluarga, 2008.

Bogdan, R.C. and Biklen, K., Qualitative Research for Education: An Introduction to Theory and Methods, Boston: Allyn and Bacon.Inc, 1982.

Departemen Agama RI, Petunjuk Teknis Pembinaan Gerakan Keluarga Sakinah, Jakarta: Bimas Islam dan Penyelenggaraan Haji Direktorat Urusan Agama Islam, 2003.

----------, Tanya Jawab Seputar Keluarga Sakinah, Jakarta: Bimas Islam dan Penyelenggaraan Haji Direktorat Urusan Agama Islam, 2003.

Dokumen Buku Diktat Konseling Pra-Nikah GKKB Jemaat Pontianak

Gilarso, T., Pembinaan Persiapan Keluarga; Membangun Keluarga Kristiani, Yogyakarta: Kanisius, 1996.

Hardana, Timotius I Ketut Adi, Kursus Persiapan Perkawinan, Jakarta: Obor, 2013. 
Harjanti, Sri, "Peran BP4 dalam Meresolusi Konflik Perkawinan (Studi Kasus KUA Kecamatan Pemangkat Kabupaten Sambas KAL-BAR Tahun 2008-2010)”, Tesis tidak diterbitkan, Yogyakarta: Hukum Islam konsentrasi Hukum Keluarga, 2010.

Hasan, Iqbal, Pokok-Pokok Materi Penelitian dan Aplikasinya, Jakarta: Graha Indonesia, 2002.

Hasil Munas BP4 VIII, Anggaran Dasar dan Anggaran Rumah Tangga, Yogyakarta: BP4 DIY, 1989.

Huda, Mahmud, "Peran BP4 Sebelum dan Sesudah Undang-undang Nomor 4 Tahun 2004 Tentang Kekuasaan Kehakiman (Studi Kasus BP4 di Kabupaten Jombang Jawa Timur)", Tesis tidak diterbitkan, Yogyakarta: Hukum Islam Konsentrasi Hukum Keluarga, 2010.

Keputusan Direktur Jenderal Bimbingan Masyarakat Islam dan Urusan Haji Nomor: D/71/1999 Tentang Petunjuk Pelaksanaan Pembinaan Gerakan Keluarga Sakinah.

Khakim, Lukman, "Peran BP4 terhadap Efektifitas Kursus Pra Nikah dalam Mengarungi Terjadinya Perceraian (Studi pada BP4 Kecamatan Parung Kabupaten Bogor), Skripsi tidak diterbitkan, UIN Syarif Hidayatullah Jakarta, 2014.

Kurniawati, Ida, “Analisis Pembinaan Keluarga Sakinah Pada Pasangan Pra-nikah Di Kantor Urusan Agama (KUA) Kecamatan Bringin Kabupaten Semarang Tahun 2012,” Skripsi tidak diterbitkan, STAIN Salatiga, 2013.

Modul Konseling Pra-Nikah GKKB Jemaat Pontianak.

Moleong, Lexy J., Metodologi Penelitian Kualitatif, Bandung: PT Remaja Rosdakarya, 2006.

Narbuko, Cholid dan Abu Achmadi, Metodologi Penelitian, cet. 8, Jakarta:PT. Bumi Aksara, 2007.

Peraturan Direktur Jenderal Bimbingan Masyarakat Islam Kementerian Agama Nomor DJ.II/542 Tahun 2013 Tentang Pedoman Penyelenggaraan Kursus Pra-Nikah.

Poerwadarminta, W. J. S, Kamus Umum Bahasa Indonesia, Jakarta: Balai Pustaka, 1976.

Rafiah, Nur, dkk, Modul Keluarga Sakinah Berperspektif Kesetaraan Bagi Penghulu, Penyuluh, dan Konselor BP4, Cetakan Pertama, Jakarta: Puslitbang Kehidupan Keagamaan. 
Riyanto, Yatim, Metodologi Penelitian Pendidikan Kualitatif dan Kuantitatif, Surabaya: UNESA University Press, 2007.

Rubiyatmoko, Robertus, Perkawinan Katolik Menurut Kitab Hukum Kanonik, Yogyakarta: Kanisius, 2011.

Sugiyono, Metode Penelitian Kuantitatif, Kualitatif dan R\&D, Bandung: ALFABETA, 2014.

Suprayogo, Imam, Metodologi Penelitian Sosial-Agama, Bandung: PT. Remaja Rosdakarya, 2001.

The New Oxford Illustred Dictionary, Oxford University Press, 1982.

Tihami, M. A. dan Sohari Sahrani, Fikih Munakahat: Kajian Fikih Nikah Lengkap, Cet. III, Jakarta: Rajawali Press, 2013.

Tim Pusat Pendampingan Keluarga "Brayat Minulyo", Kursus Persiapan Hidup Berkeluarga, Yogyakarta: Kanisius, 2007. 